Etikonomi

Volume 15 (1), April 2016

P-ISSN: 1412-8969; E-ISSN: 2461-0771

Page 31-42

\title{
HOW FAR HAS OUR WAQF BEEN RESEARCHED?
}

\author{
Aam Slamet Rusydiana, Salman Al-Farisi \\ SMART Consulting \\ aamsmart@gmail.com, salman@gmail.com
}

\begin{abstract}
In practice, waqf in Indonesia faces many hard problems, because commonly known as nonproductive waqf. Talking about waqf, it's not only as religious rituality but also could touch humanity aspect by empowering its potency to maximize public wealth. On the other hand, the research related to waqf is still very lack, but it is very important to do. This study reviews on research around waqf. The study used descriptive statistical analysis based on 100 journal publications related to waqf, both national and international journal. The entire sample journal publications have published last 5 years from 2011 to 2015. Results show that the waqf research is still dominated by the discussion of non-cash waqf (62\%) then the cash waqf (38\%). This gives a general overview for researchers to produce better research related to cash waqf. In addition, comparison of quantitative research methods is still far less than the qualitative approach.
\end{abstract}

Keywords: Waqf literatures; Issue; Research on Waqf

\begin{abstract}
Abstrak.
Dalam prakteknya, wakaf di Indonesia menghadapi banyak masalah, karena umumnya dikenal sebagai wakaf non-produktif. Berbicara tentang wakaf, tidak hanya sebagai ritual agama tetapi juga bisa menyentuh aspek kemanusiaan dengan memberdayakan potensinya untuk memaksimalkan kekayaan publik. Di sisi lain, penelitian yang berkaitan dengan wakaf masih sangat kurang, tapi sangat penting untuk dilakukan. Kajian ini berupaya meninjau penelitianpenelitian terkait wakaf. Penelitian ini menggunakan analisis statistik deskriptif berdasarkan 100 publikasi jurnal terkait wakaf, baik jurnal nasional dan internasional. Seluruh sampel publikasi jurnal ialah yang diterbitkan pada 5 tahun terakhir dari 2011 hingga 2015. Hasil menunjukkan bahwa penelitian wakaf masih didominasi oleh pembahasan wakaf non-tunai (62\%) sedangkan wakaf tunai (38\%). Hal ini memberikan gambaran umum bagi para peneliti untuk menghasilkan penelitian yang lebih baik terkait dengan wakaf tunai. Selain itu, perbandingan metode penelitian kuantitatif masih jauh lebih sedikit dibandingkan dengan pendekatan kualitatif.
\end{abstract}

Kata Kunci: Literatur Wakaf; Isu; Penelitian Wakaf

Received: December 27, 2015; Revised: February 3, 2016; Approved: March 12, 2016 
How Far Has Our Wakaf Been Researched?

Aam Slamet Rusydiana, Salman Al-Farisi

\section{INTRODUCTION}

The instrument of waqf is one of Islamic law regarding the life of society as acts of worship ijtima'iyyah which is working for community interests in order to devote Allah SWT. In addition, Islam has institutional preparation to obtain the funds to the poor communities can stand on its own. To achieve this goal, one can be given through waqf besides from the payment required (zakat) and voluntary payment contribution others. So if this waqf instrument is developed and managed productively, it can serve as an alternative for poverty reduction.

In act context, waqf is defined specifically to work of waqif to deliver some of his wealth to be used forever or for a certain period of time in accordance with its importance to the necessity of worship and the public welfare according to the Islami.

In practical, waqf in Indonesia is now faced with the problems that are quite complex because most of waqf nonproductive and operational cost is a burden on society. This fact illustrates the waqf condition that defined by Mundzir Qahf is directly waqf, not productive waqf. This means that the waqf that provides services directly to the community, waqf is no provided for production matter.

Institution of waqf is currently not only as a religious ritual but also it can touch the humanity aspect by empowering the potential for public welfare. On the other side, of the research and development related to waqf and its management is still very less, though this is very important to be done. Compared to the zakat, research about waqf is still low from quantity side, both in the world especially in Indonesia.

Based on the background described above, the formulation of the problem in this research is as follows: (1) What are the areas of waqf study and how the percentages? (2) In the approach research methodology, how the composition of the research related to waqf in general? (3) How the percentage of the number of publications, research types, research approach, the subject adjacent to the area of waqf study during the last 5 years? 


\section{METHOD}

The study on this research focuses on the exploration of 100 researches up to date related to the waqf that has been published on scientific journals. There are some issues that will know the answer. For instance, what percentage related to waqf research during 5 years period? How does the type of waqf research and its composition. How to approach waqf research associated with the use of quantitative research, qualitative or mixed method.

In addition, focus on this study also tries to examine more in any related to quantitative research methods that are used and what the dominant. How the subject of the discussion about waqf and its composition is. Then, relation with cash waqf issues, how the composition of research on the cash waqf theme and research non-cash waqf. Unless important, which country that study and publish the waqf research in the world.

This research used descriptive statistics analysis based on 100 publications journals related waqf, both national and international. All samples of the publication of the journal have been published 5 years starting from 2011 to 2015. The study only focuses on the journal article with titled waqf specifically.

Next, after review and analysis, the research that related to waqf is divided into 4 (four) main categories i.e. first, Waqf Management. Second, Waqf Distribution. Third, Waqf Institutions. Fourth, the Collection of waqf. This classification is made based on the study, abstraction and the entire research in general. Even though there is a correlation possibility among and category classification.

\section{DISCUSSION}

There are 100 journal that have been published both national and international journals are selected which are related to waqf from 5 years observation, from 2011 to 2015. Table 1 describes the distribution of the journal per year. This shows the number of the variety of published journal with the range of 8 to 32 journals. The majority of publication is in 2014. The publication of the journal is less than other year i.e. in 2011. 
Table 1. The number of publications per year

\begin{tabular}{ccc}
\hline Year of Publication & Number of Article & Percentage \\
\hline 2011 & 8 & 0.08 \\
2012 & 20 & 0.2 \\
2013 & 10 & 0.1 \\
2014 & 32 & 0.32 \\
2015 & 30 & 0.3 \\
Total & $\mathbf{1 0 0}$ & $\mathbf{1}$ \\
\hline
\end{tabular}

Table 2 shows the type of research that used for each publication Journal that observed. According to Sekaran (2013), in general, there are four types of research i.e. analysis, descriptive, empirical, and exploratory research. This observation uses only three types of research i.e. analysis, descriptive and empirical. First, research analysis is used to answer the question why certain things or how that can be happened. The type of this research is usually related to cause and effect. Second, the descriptive research determines, describes, or identifies the specific things. Descriptive research uses classification, measurement and comparison for describing a phenomenon. Third, empirical research method is the research method that uses the observation field studies (empirical) or data collected from the question and answer as in the form of a questioner.

Table 2. The Type of Research on Each Publication

\begin{tabular}{crrrr}
\hline Year of & \multicolumn{3}{c}{ Research Types } & \multirow{2}{*}{ Total } \\
\cline { 2 - 5 } Publication & Analytical & Descriptive & Empirical & \\
\hline 2011 & 0 & 7 & 1 & 8 \\
2012 & 2 & 14 & 4 & 20 \\
2013 & 2 & 7 & 1 & 10 \\
2014 & 9 & 19 & 4 & 32 \\
2015 & 7 & 20 & 3 & 30 \\
Total & $\mathbf{2 0}$ & $\mathbf{6 7}$ & $\mathbf{1 3}$ & $\mathbf{1 0 0}$ \\
\hline
\end{tabular}

From table 2, it can be shown that the most type of research methodology from published journal (national and international) from 2011 to 2015 is descriptive research methodology such as: 67 journals, then followed by the analysis method of some 20 journals and the last is an empirical research method as much as 13 journals. 
According to Punch (2013), there are 3 types of research approach i.e. qualitative approach, quantitative approach and mixed method approach (mixed method). Table 3 shows the research methodology used for each published journal in 5 years period from 2011 to 2015. The most used research method is the qualitative approach some 81 journals. Then the quantitative approach some 15 journals and the mixed method is only 4 journals.

Table 3. Research Approach on Each Publication

\begin{tabular}{ccccc}
\hline \multirow{2}{*}{ Year of Publication } & \multicolumn{3}{c}{ Research Types } & \multirow{2}{*}{ Total } \\
\cline { 2 - 5 } & Qualitative & Quantitative & Mixed & \\
\hline 2011 & 8 & 0 & 0 & 8 \\
2012 & 18 & 1 & 1 & 20 \\
2013 & 8 & 2 & 0 & 10 \\
2014 & 24 & 7 & 1 & 32 \\
2015 & 23 & 5 & 2 & 30 \\
Total & $\mathbf{8 1}$ & $\mathbf{1 5}$ & $\mathbf{4}$ & $\mathbf{1 0 0}$ \\
\hline
\end{tabular}

This section shows the type of quantitative research methodology used in 100 selected published Journals. In 100 journals there are 12 waqf quantitative research method that is used as the following Customer Satisfaction Index (CSI), Contingent Custom, Factor Analysis, System Dynamic, Partial Least Square (PLS), Logit, ANOVA, T- Test, Analytic Hierarchy Process (AHP), Structural Equation Model (SEM), MANOVA, and Multiple Regression. The factor analysis method is the most used to study the waqf i.e. 5 journals.

Table 4 shows the subject of the discussion of each journal related to waqf based on published waqf journal between 2011 and 2015. This observation based on the four subjects that are related to the waqf management, waqf distribution, waqf institutions, and waqf collection. From the publication 2011 to 2015, it was selected that the subject of the discussion the waqf management topic. It was about 34 journals, and then followed by the waqf institution was some 26 journals, waqf collection was some 22 journals and the waqf distribution was 18 journals, respectively. 
Table 4. The Subject of Waqf Journal

\begin{tabular}{lcccccc}
\hline \multirow{2}{*}{ Subjects of Article } & \multicolumn{7}{c}{ Year of Publication } & \multirow{2}{*}{ Total } \\
\cline { 2 - 6 } & $\mathbf{2 0 1 1}$ & $\mathbf{2 0 1 2}$ & $\mathbf{2 0 1 3}$ & $\mathbf{2 0 1 4}$ & $\mathbf{2 0 1 5}$ & \\
\hline Management & 3 & 7 & 3 & 10 & 11 & 34 \\
Distribution & 2 & 4 & 5 & 4 & 3 & 18 \\
Institution & 3 & 9 & 2 & 6 & 6 & 26 \\
Collection & 0 & 0 & 0 & 12 & 10 & 22 \\
\multicolumn{1}{c}{ Total } & $\mathbf{8}$ & $\mathbf{2 0}$ & $\mathbf{1 0}$ & $\mathbf{3 2}$ & $\mathbf{3 0}$ & $\mathbf{1 0 0}$ \\
\hline
\end{tabular}

Table 5 shows the subject of waqf type based on 100 published journals from 2011 to 2015. There are 2 types of waqf i.e. cash and non-cash. From 100 published journals, the discussion on non-cash waqf more than cash waqf. It is about 62 journals, while the cash waqf is only 38 journals.

Table 5. The subject of Waqf Type

\begin{tabular}{crrrrrr}
\hline \multirow{2}{*}{ Subjects of Article } & \multicolumn{5}{c}{ Year of Publication } & \multirow{2}{*}{ Total } \\
\cline { 2 - 6 } & $\mathbf{2 0 1 1}$ & $\mathbf{2 0 1 2}$ & $\mathbf{2 0 1 3}$ & $\mathbf{2 0 1 4}$ & $\mathbf{2 0 1 5}$ & \\
\hline Cash & 3 & 8 & 5 & 15 & 7 & 38 \\
Non-Cash & 5 & 12 & 5 & 17 & 23 & 62 \\
Total & $\mathbf{8}$ & $\mathbf{2 0}$ & $\mathbf{1 0}$ & $\mathbf{3 2}$ & $\mathbf{3 0}$ & $\mathbf{1 0 0}$
\end{tabular}

This section describes the list of publication ranking based on geographical location. It is divided into 2 parts, that are the study location of the selected published journals and the publication location the journals. First, Malaysia becomes the most area of study related to the waqf research (37 journals), followed by the Indonesia (29 journals), Nigeria (4 journals), Turkey, the OIC Countries and Bangladesh (3 journals), Jordan, Saudi Arabia, and Egypt (2 journals), and other countries (1 journal). In terms of the area of published journal, Indonesia is the most waqf research (34 journals), USA (13 journals), Malaysia (10 journals), the UK (9 journals), Saudi Arabia, Bangladesh (4 journals), Australia, India, and Turkey (3 journals), Africa, China, Italy, Pakistan (2 journals), and other countries ( 1 journal).

In addition, table 6 shows the sub country which becomes area of the waqf research. The group of countries which the most becomes waqf research area are South East Asia (68 countries), Middle East (10 countries), Africa (7 countries), South Asia (5) and other countries (10 countries). 
The area of waqf research publication is 79 types of journals. On this research, Tazkia Islamic Finance and Business Review, and the International Journal of the Archipelago Islam became the most journal that published 100 journals related to waqf are each number is 4 Journals, then followed by the International Journal of Trade, Economics and Finance (3 journals), Australian Journal of Basic and Applied Sciences (3 journals), International Journal of Business Economics and Law (3 journals), and Asy-Syir'ah the journal of shari'ah and the Law (2 journals), Ahkam (2 Journals), ISLAMICA (2 Journals), ISRA International Journal of Islamic Finance (2 Journals), International Review of Social Sciences and Humanities (2 journals), Islamic Economic Studies (2 journals), Life Science (2 journals), Advances in Environmental Biology (2 journals), Journal of Islamic Economics Banking and Finance (2 journals), and other (1 journal).

Table 6. Sub Studied Area

\begin{tabular}{lc}
\hline \multicolumn{1}{c}{ Studied Area } & Number \\
\hline South East Asia & 68 \\
Middle East & 10 \\
Africa & 7 \\
South Asia & 5 \\
Other & 10 \\
\hline
\end{tabular}

There are several important findings related to the waqf. Analysis of 100 publication journals related to waqf study from 2011 to 2015 is as follows: First, there are many discussions related to waqf journal that published has discussed. The most publication is in 2014 as much as 32 journals. Second, generally, the author prefers using descriptive research methods to answer the waqf phenomenon in a certain countries such as: 67 journals while the analysis method is 20 journals, and the empirical method is 13 journals. Third, in general, from 100 publication journals uses the qualitative approach to elaborate the waqf as much as 81 Journals, quantitative approach is 15 journals, and mixed method is 4 journals. Fourth, the subject waqf journal is more related to the waqf management and then followed by waqf institutions, and the collection and distribution of waqf. Fifth, Malaysia is the most area of waqf study meanwhile Indonesia journal becomes majority on publication of waqf journal. 
This result can be seen that the issue of waqf becomes intensive discussions by Moslem experts from year to year. This is shown with the publication of the journal of the last 2 years such as: 2014 and 2015 are more than the previous year. In addition, the issues of waqf more examined or discussed using descriptive methods and qualitative research. The subject discussion that the most discussed is the waqf management. The waqf management is suspected to have a crucial role for increasing the effectiveness of waqf. In addition, the discussion of waqf is still dominated by non-cash waqf.

\section{CONCLUSION}

Research on waqf has an important role to the Moslem society in realize benefits from the fund management optimization waqf for empowering the local economy. The discussion of waqf was still dominated by the discussion of the noncash waqf rather than the cash waqf from 2011 to 2015, this provides an overview in general for researchers or experts to discuss more that related to the cash waqf. It has a great power in collecting funds from the community then it is used as a waqf productive for empowering the local economy. In addition, comparison of quantitative research method is still far less than the qualitative approach. This is the potential for increasing the waqf research using quantitative methods.

\section{REFERENCES}

Afandi, M.B.M.R. (2015). Fatwa on Waqf: Specialized Analysis in Hand over of Waqf Lands by State Authority. International Journal of Nusantara Islam, Vol. 3 (1), pp. 47- 58.

Ahmad, M, et.al. (2014). Online Waqf Acceptance and Determinant Factors. International Journal of Business, Economics and Law, Vol. 5, Issue 2, pp. 231-242.

Ahmad, M. \& Y.B. Hassan. (2015). Funding The Sub-Saharan African Education Sector With Waqf: Experiences From Al-Azhar University And Selected Universities In Malaysia. Journal of Creative Writing Volume 1, Issue 2, pp 40-54. 
Ahmad, M. (2015). Role of Waqf in Sustainable Economic Development and Poverty Alleviation: Bangladesh Perspective. Journal of Law, Policy and Globalization, Vol. 42, pp. 111-120.

Ahmed, U. et.al. (2015). Investigating the Influence of Public Trust on the Revival of Waqf Institution in Uganda. Middle-East Journal of Scientific Research 23 (6): 1165-1172.

Ahmed, Umar. et.al. (2015). Examining the Traditional Waqf Based Financing Methods and Their Implications on Socio-Economic Development. IOSR Journal of Business and Management (IOSR-JBM) Vol. 17 (2), pp. 119-125.

Al Arif, M.N.R. (2012). Efek Multiplier Wakaf Uang dan Pengaruhnya Terhadap Program Pengentasan Kemiskinan (Multiplier Effect Waqf money and its effects on Poverty Alleviation Programs). Asy-Syir'ah: Jurnal Ilmu Syariah dan Hukum, Vol. 46 No. 1, pp. 297-314.

Al Arif, M.N.R.(2012). Wakaf Uang dan Pengaruhnya Terhadap Program Pengentasan Kemiskinan di Indonesia (Waqf money and its effects on poverty alleviation programs in Indonesia). Indo-Islamika, Volume 2, No. 1, pp. 17-29.

Almanaseer, M. \& B. Matarneh. (2014). Waqf and its Role in The Social and Economic Development of the Hashemite Kingdom of Jordan. The Journal of Economics and Sustainable Development, Vol. 5, No.15, pp. 1167-1176.

Ali, R. et.al. (2015). Creating Young Entrepreneurs in Malaysia through Waqf Structuration Framework. Australian Journal of Basic and Applied Sciences, 9(28), pp. 225-229.

Alias, T.A. \& M. Cizakca. (2014). Solution Malaysian States have a Fresh Approach to Waqfs? A proposal for A Model of Waqf Enactment. ISRA-International Journal of Islamic Finance Vol. 6 No. 2, pp. 201-210.

Aminuddin, M.Z. (2011). Masalah Pendistribusian Manfaat Pengelolaan Wakaf: Kajian Terhadap UU No. 41 Tahun 2004 Tentang Wakaf (The problem of the distribution of the benefits of the Management of Waqf: Review of Act No. 41 The year 2004 about Waqf). Asy-Syir'ah Jurnal Ilmu Syariah dan Hukum, Vol. 45, No. 2, pp. 1497-1522. 
Amin, H. et.al. (2014). Determinant of Online Waqf Acceptance: An Empirical Investigation. The Electronic Journal on Information Systems in Developing Countries EJISDC, Vol. 60, No. 8, pp 1-18.

Amuda, Y.J. \& N.A.C. Embi. (2013). Alleviation of Poverty Among OIC Countries Through Sadaqat, Cash Waqf and Public Funding. The International Journal of Trade, Economics and Finance, Vol. 4, No. 6, pp. 501-510.

Amuda, Y.J. et.al. (2014). Is more Participatory Approach to the of Cash Waqf as Malaysia and Nigeria. The Journal of Advanced Management Science, Vol. 2 (4), pp. 344-348.

Amuda, Y.J. \& A.H. Buang. (2015). Mixed Methods on the Commercialization of Cash Waqf in Nigeria: An Analysis of Its Implementation. IOSR Journal of Economics and Finance (IOSR-JEF), Vol. 6 (3), pp. 90-97.

Amuda, Yusuff Jelili and Hidayat, Ahmad bin Buang. (2015). "The Application of Cash Waqf as an Instrument for Socio-Economic Development in Nigeria”. International Journal of Economics, Commerce and Management Vol. III, Issue 5, 601-610.

Arafa, M.A. (2014). Islamic Policy of Environmental Conservation: 1500 Years Old yet Throughly modern. European Journal of Law Reform 16 (2), pp. 251-260.

Aziz, M.R. et.al. (2013). Assessment on the lack of willingness among Public in contributing for Social Islamic Waqf bank for Education. The Australian Journal of Basic and Applied Sciences, 7(13), pp. 172-176.

Aziz, M.R. \& M.A. Yusof. (2014). Examining the Relationship Between the Level of Income and Appointment of Agent in Collecting Waqf Fund. The International Journal of Trade, Economics and Finance, Vol. 5, No. 2, pp. 201212.

Aziz, M.R. \& M.A. Yusof. (2015). Scrutinizing the Method of Contribution for Islamic Waqf Bank Fund. Journal of Islamic Economics, Banking and Finance, Vol. 11 (1), pp. 31-42.

Babacan M. (2011). Economics of Philanthropic Institutions, Regulation and Governance in Turkey. The Journal of Economic and Social Research Vol 13(2) 2011, pp. 61-89. 
Bahroni, Imam. (2012). "Streamlining Education Institution through Waqf Enlargement: An Experience of Gontor System". The Journal At- Ta'dib Vol. 7 No. 2, pp. 181-192.

Chowdhury, Md. S.R, et.al. (2011). Economics of Cash Waqf Management in Malaysia: A Proposed Cash Waqf Model for Practitioners and Future Researchers. African Journal of Business Management, Vol. 5(30), pp. 1215512163.

Chowdhury, Md. Shahedur Rahaman, Chowdhury, Iftekhar Amin Muhammad, Mohd Zulkifli. (2012) "Problems of Waqf Administration and Proposals for Improvement: A Study in Malaysia". Journal of Internet Banking and Commerce, Vol. 17 (1), pp. 11-22.

Darwanto. (2012). Wakaf Sebagai Alternatif Pendanaan Penguatan Ekonomi Masyarakat Indonesia (Waqf as Alternative Funding Strengthening the Economy of Indonesian Society). Jurnal Ilmu Manajemen dan Akuntansi Terapan, Vol. 3 (1), pp. 31-40.

Diharto, A.K. (2012). Merekonstruksi Model Pengelolaan Harta Wakaf Tradisional Untuk Merevitalisasi Peran Wakaf Bagi Pemberdayaan Ummat (Reconstruct the Wealth Management Model Traditional Waqf to Revitalize the Role of Waqf for Empowerment for Ummat). El-Pronounced Hayah Impress: Ilmuilmu Jurnal, Vol. 1 No. l, pp. 91-100.

Fanani, M. (2011). Cash Waqf Management. Walisongo, Vol. 19 No. 1, pp. 81-90.

Mohammad, M.T.S. 2011. Toward an Islamic Social (Waqf) Bank. The International Journal of Trade, Economics and Finance, Vol. 2, No. 5, pp. 401-410.

Mohsin, M.I.A. (2013). Financing through Cash Waqf: A Revitalization to Finance Different Needs. International Journal of Islamic and Middle Eastern Finance and Management Vol. 6 (4), pp. 304-321.

Haq, A.F. (2012). Wakaf Kontemporer: Dari Teori ke Aplikasi (Contemporary Waqf: From theory to Applications). Maliyah Vol. 2 No. 2, pp. 171-180.

Htay, S.N.N. et.al. (2013). Integrating the zakat and Sadaqah Waqf: Myint Myat Phu Zin Clinic Model in Myanmar. Tazkia Islamic Finance and Business Review, Volume 8 (2), pp. 151-160. 
Huda, M. (2013). Model Manajemen Fundraising Wakaf (Waqf Fundraising Management Model). Ahkam: Vol. XIII, No. 1, pp. 81-90.

Ibrahim, H. et.al. (2013). Cash Waqf: An Innovative Instrument for Economic Development. International Review of Social Sciences and Humanities Vol. 6, No. 1 (2013), pp. 1-7.

Ismail, N.A. (2013). In Search of Debt Free Economic Development: The Role of Zakah and Awqaf Funds. The International Journal of Advances in Management and Economics, Vol. 2 (5), pp. 70- 78.

Punch, K.F. (2013). Introduction to Social Research: quantitative and qualitative Approaches. USA: Sage Publishing.

Sekaran, U. (2013.) Research Methods for Business: A Skill-Building Approach, 6th Edition. USA: Wiley.

Suwaidi, A. (2011). Wakaf dan Penerapannya di Negara Muslim (Waqf and its Application in Muslim Countries). Jurnal Ekonomi dan Hukum Islam, Vol. 1 (2), pp. 201-212.

Zakariya, M.B.M. \& A.A Salihu. (2011). New Dimension in the Mobilization of Waqf Funds for Educational Development. Kuwait Chapter of Arabian Journal of Business and Management Review, Vol. 1 No. 1, pp. 21-30.

Zamil, A.M. \& M.M. Shammot. (2011). Role of Measuring Customer Satisfaction in Improving the Performance in the Public Sector (Waqf) Organization. The Journal of Business Studies Quarterly 2011, Vol. 2, No. 3, pp. 32-41. 